\section{Hormonal response and root architecture in Arabidopsis thaliana subjected to heavy metals}

\author{
Antonella Vitti, ${ }^{1}$ Maria Nuzzaci, ${ }^{1}$ \\ Antonio Scopa, ${ }^{1}$ Giuseppe Tataranni, ${ }^{2}$ \\ Imma Tamburrino, ${ }^{1}$ Adriano Sofo ${ }^{1}$ \\ ${ }^{1}$ School of Agricultural, Forestry, Food \\ and Environmental Sciences, University \\ of Basilicata, Potenza; ${ }^{2}$ Department of \\ European and Mediterranean Cultures, \\ Architecture, Environment and Cultural \\ Wealth, University of Basilicata, Matera, \\ Italy
}

\section{Abstract}

In this work, specific concentrations of cadmium, copper and zinc in double combination, were supplied for 12 days to growing seedlings of the model species Arabidopsis thaliana. Metal accumulation was measured in roots and shoots. Microscopic analyses revealed that root morphology was affected by metals, and that the root and shoot levels of indole-3-acetic acid, trans-zeatin riboside and dihydrozeatin riboside varied accordingly. Minor modifications in gibberellic acid levels occurred in the Zinc treatments, whereas abscisic acid level did not change after the exposition to metals. Reverse transcription polymerase chain reaction analysis of some genes involved in auxin and cytokinin synthesis (AtAAO, AtNIT and AtIPT) revealed that their expression were not affected by metal treatments. The root morphological alterations that resulted in an increased surface area, due to the formation of root hairs and lateral roots, could be signs of the response to metal stress in terms of a functionallyaddressed reorientation of root growth. The root system plasticity observed could be important for better understanding the manner in which the root architecture is shaped by environmental and hormonal stimuli.

\section{Introduction}

Understanding the metabolic answer and the adaptation of plants towards toxic metal exposure can open the way to future phytoremediation of contaminated sites. ${ }^{1}$ In particular, excess cadmium $(\mathrm{Cd})$, copper $(\mathrm{Cu})$ and zinc $(\mathrm{Zn})$ are known to induce stress effects in all plant species. ${ }^{2}$ However, while homeostatic $\mathrm{Cu}$ and $\mathrm{Zn}$ concentrations are normally present in different soils and are part of or act as cofac- tors of many cell macromolecules, plants do not usually experience elevated $\mathrm{Cd}$ stress under normal environmental conditions and thus have no metabolic requirement for this metal. ${ }^{3}$

Arabidopsis thaliana L. (Arabidopsis) is considered a model plant for many studies as its genomic sequence was completely identified and its mechanisms in genomic, transcriptomic and proteomic regulation are often similar to other plant species. Arabidopsis plants subjected to different types of abiotic stresses can show alterations in phytohormone levels when compared to non-stressed control plants., ${ }^{4,5}$ Particularly, indole-3-acetic acid (IAA) and its metabolites are the most widely auxins in plants. $^{5-7}$ Trans-zeatin riboside ( $t$-ZR) and dihydrozeatin riboside (DHZR), two of the most important natural cytokinins (CKs), are implied in meristem activity, de novo bud formation, release from apical dominance, leaf expansion, reproductive development, and senescence. Furthermore, in Arabidopsis, Cdinduced inhibitory effects were reported to be concomitant with an increase in endogenous abscisic acid (ABA) in plant tissues, indicating the possibility of this phytohormone mediating a part of the metal-imposed phytotoxicity. ${ }^{8}$ In Arabidopsis, gibberellins (GAs), another class of phytohormones, affect almost every aspect of plant growth and development, particularly florigenic activity, stem growth through cell elongation and increased expression of several genes, and are regulated by complex control mechanisms. ${ }^{9-12}$

On this basis, the aim of this work was to investigate metal accumulation, morphological root modifications and changes in the levels of phytohormone related to their genetic regulation in Arabidopsis seedlings exposed to $\mathrm{Cd}, \mathrm{Cu}$ and $\mathrm{Zn}$ in double combinations, as the presence of more than one metal is the common situation of polluted soils. ${ }^{1,3}$ As a model plant, Arabidopsis can be important for a better understanding of the fundamental aspects of the mechanisms involved in metal homeostasis, detoxification and tolerance in plants that could be used for phytoremediation purposes.

\section{Materials and Methods}

\section{Plant material and experimental design}

Seeds of Arabidopsis thaliana (L.) Heinh. (Columbia ecotype; Col-0) were sterilized using $50 \%(\mathrm{v} / \mathrm{v})$ ethanol for $5 \mathrm{~min}$ followed by 5 min of 1\% Na-hypochlorite, and finally rinsed with sterile $\mathrm{dH}_{2} \mathrm{O}$, before imbibition on moist filter paper at $4^{\circ} \mathrm{C}$ for $24 \mathrm{~h}$ in the dark. Then, seeds were put in $3 \mathrm{~cm}$-height polyethylene tubes (one container per treatment, with 65 tubes per container, each with one seed)
Correspondence: Antonio Scopa, School of Agricultural, Forestry, Food and Environmental Sciences (SAFE), University of Basilicata, Via dell'Ateneo Lucano 10, 85100 Potenza, Italy. Tel. +39.0971.205240 - Fax: +39.0971.205378. E-mail: antonio.scopa@unibas.it;

Key words: abiotic stresses, cadmium, copper, hormones, zinc.

Contributions: ASo, experimental plan, plant culture, hormones extraction and determination, manuscript writing; $\mathrm{AV}$, gene expression analysis; MN, metals analysis; GT, microscopy and morphometric analysis; IT, nucleic acid extraction and primers design; ASc, statistical analysis and laboratory setting.

Conflict of interests: the authors declare no potential conflict of interests.

Received for publication: 4 December 2013. Accepted for publication: 23 April 2014.

This work is licensed under a Creative Commons Attribution NonCommercial 3.0 License (CC BYNC 3.0).

(C) Copyright A. Vitti et al., 2014

Licensee PAGEPress srl, Italy

International Journal of Plant Biology 2014; 5:5226 doi:10.4081/pb.2014.5226

closed at the bottom with a polyethylene net, and filled with sterilized sand (mean particle diameter $=0.25 \mathrm{~mm}$, in order to allow an efficacious and rapid root extraction from the sand, without tissue damage). Each container was moistened with $3 \mathrm{~L}$ of one-quarter strength Hoagland liquid medium, continuously aerated by an air pump, and replaced throughout the experiment in order to maintain a constant volume and to keep the roots moistened. Seedlings were grown in a growth chamber at $20^{\circ} \mathrm{C}$ with a 16 -h photoperiod and a photosynthetic photon flux density of 300 $\mu \mathrm{mol} /(\mathrm{m} s)$ at leaf level. Two-week-old seedlings were subsequently exposed to $10 \mu \mathrm{M}$ $\mathrm{CdSO}_{4}, 5 \mu \mathrm{M} \mathrm{CuSO}$, an $150 \mu \mathrm{M} \mathrm{ZnSO}$ in double combination $(\mathrm{Cd} / \mathrm{Cu}, \mathrm{Cd} / \mathrm{Zn}$ and $\mathrm{Cu} / \mathrm{Zn})$, simulating the concentrations possibly present in the soils contaminated by these three metals. ${ }^{1}$ The metals were added directly to the Hoagland's solution. After 12 days of exposure to the metals, roots and shoots were separated and immediately analysed. The 12-day exposure period was chosen on the basis of previous experiments for avoiding toxic metal accumulation in Arabidopsis plants. ${ }^{1,13}$ Control plants were not treated with metals.

\section{Morphological analysis}

Shoot height (flowering stem), primary root length, and rosette diameter were measured 
on 20 randomly selected seedlings per treatment $(n=20)$. Fresh root systems from 10 seedlings were immediately mounted on slides and observed using a microscope (Eclipse 80i, Nikon, Tokyo, Japan) under transmitted light, and then photographed (Digital Camera DSFil, Nikon). Root hairs density (evaluated as hair number normalized to root length), root branching (number of lateral roots normalized to root length), and mean root diameter (measured at $0.02 \mathrm{~cm}$ from the tips of primary and lateral roots), were measured using the NISElements Imaging Software (Nikon). Root branching and root hairs density were calculated at the same position for each treatment.

\section{Metals determination}

Roots were carefully rinsed twice with 10 mM CaCl 2 and then with $\mathrm{dH}_{2} \mathrm{O} .{ }^{14}$ Aliquots of shoots and roots $(1 \mathrm{~g})$ were digested in a $\mathrm{HNO}_{3}: \mathrm{H}_{2} \mathrm{O}_{2}$ solution $(5: 1 \mathrm{v} / \mathrm{v})$, by using a high performance microwave digestion unit (MLS1200 Mega, Milestone Inc., CT, USA). The levels of $\mathrm{Cd}, \mathrm{Cu}$ and $\mathrm{Zn}$ were determined by inductively coupled plasma-optical emission spectrometry (ICP-0ES; model iCAP 6000, ThermoScientific, Cambridge, UK). Blanks (only $\mathrm{HNO}_{3}$ and $\mathrm{H}_{2} \mathrm{O}_{2}$ ) and a standard stock solution of 50 $\mu \mathrm{mol} / \mathrm{L}$ for each element were analyzed for reference purposes. The analysis was carried out on ten independent replicates $(\mathrm{n}=10)$.

\section{Phytohormone extraction and analysis}

Aliquots of $250 \mathrm{mg}$ of shoot and root tissues were homogenized in a mortar ice in $2.5 \mathrm{~mL}$ of 2-propanol/ $\mathrm{H}_{2} \mathrm{O} / \mathrm{HCl} 37 \%$ (2:1:0.002, v/v/v). To each sample, $2.5 \mathrm{~mL}$ of dichloromethane was added, and subsequently the samples were centrifuged at $13,000 \times \mathrm{g}$ for $5 \mathrm{~min}$. Subsequently, $1.0 \mathrm{~mL}$ of the solvent from the lower phase was concentrated using an evaporator with nitrogen flow, and then re-dissolved in $0.1 \mathrm{~mL}$ methanol. The quantitative determinations of IAA, $t$-ZR, DHZR, GA3 and ABA were carried out in both un-inoculated and inoculated plants by high performance liquid chromatography coupled with mass spectrometry (Shimadzu LCMS-2020 equipped with an ESI source, with two LC-2020AD pumps, CBM-20A controller and SIL-20A MS-2020 auto-sampler; Shimadzu Co., Kyoto, Japan). ${ }^{13}$

\section{Total RNA extraction and reverse transcription polymerase chain reaction analysis}

Tissues (100 mg) deriving from control and metal-exposed seedlings were ground with mortar and pestle in $1 \mathrm{~mL}$ of sterile RNase-free water. To $300 \mu \mathrm{L}$ of crude extract, $1 \mathrm{~mL}$ of TRIzol ${ }^{\circledR}$ Reagent (Invitrogen, Milan, Italy) was added. The sample was homogenized and the procedures for the dissociation of nucleoprotein complexes, phase separation, RNA precipitation, RNA washing and RNA re-dissolution were carried out as described by the manufacturer. After that RNA concentration was determined with NanoDrop 1000 Spectrophotometer (Thermo-Scientific), $500 \mathrm{ng}$ of total RNA were processed with TURBO DNAfree $^{\mathrm{TM}}$ DNase Treatment and Removal Reagents (Ambion by Life Technologies, Monza, Italy), according to the manufacturer's instructions.

Total RNA was reverse-transcribed and amplified in a single tube using the SuperScript $^{\mathrm{TM}}$ III One-Step RT-PCR System with Platinum ${ }^{\circledR}$ Taq DNA Polymerase (Invitrogen). The RT-PCR reaction mixture (a final volume of $50 \mu \mathrm{l}$ ) was prepared using an annealing temperature of $60^{\circ} \mathrm{C} .{ }^{13}$ Primer pairs were designed for the reverse transcription polymerase chain reaction (RT-PCR) of sequences belonging to genes encoding biosynthetic enzymes for rate-limiting steps of IAA and CKs biosynthetic patterns and known for being finely regulated (Table 1). ${ }^{11,12,15,16}$ The PCR fragments were fractionated on $1 \%$ agarose gel and stained with SYBR Safe ${ }^{\mathrm{TM}}$ DNA gel stain (Invitrogen). The analysis was carried out on five independent replicates $(n=5)$.

\section{Statistical analysis}

The number of replicates $(n)$ for each measured parameter is specified throughout the text, and in the table captions. The statistical analysis of data was carried out using the Sigmastat 3.1 SPSS Inc. software (SPSS Inc., IL, USA). Analysis of variance (ANOVA) of root and shoot parameters was performed with metal treatments as factors. Means were statistically analyzed by Fisher's LSD test at $\mathrm{P} \leq 0.05$.

\section{Results}

\section{Metal levels}

Metal-treated seedlings efficiently absorbed the metals, that accumulated in roots and were partly transported and stored in shoots (Table 2). The root uptake of $\mathrm{Cd}$ was subjected to a significant competition in the presence of $\mathrm{Zn}$ $(222 \mu \mathrm{g} / \mathrm{g}$ DW of $\mathrm{Cd}$ in the $\mathrm{Cd} / \mathrm{Zn}$ treatment against $305 \mu \mathrm{g} / \mathrm{g}$ DW of $\mathrm{Cd}$ in the $\mathrm{Cd} / \mathrm{Cu}$ treatment) (Table 2). The similar behavior of $\mathrm{Cd}$ was observed for $\mathrm{Zn}$ root levels in the presence of $\mathrm{Cd}(725 \mu \mathrm{g} / \mathrm{g}$ DW of $\mathrm{Zn}$ in the $\mathrm{Cu} / \mathrm{Zn}$ treatment against $461 \mu \mathrm{g} / \mathrm{g}$ DW of $\mathrm{Zn}$ in the $\mathrm{Cd} / \mathrm{Zn}$ treatment (Table 2). Therefore, a strong competition between $\mathrm{Cd}$ and $\mathrm{Zn}$ uptake was observed, whereas $\mathrm{Cu}$ levels appeared to be not significantly affected by the presence of $\mathrm{Zn}$ or Cd (Table 2).

The metals were also translocated to the shoots, where they were found in lower concentrations but in similar ratios of those in

Table 1. Primers used for the amplification of gene sequences.

\begin{tabular}{|c|c|c|c|c|c|}
\hline Gene & Gene function & $\begin{array}{l}\text { Accession number } \\
\text { (TAIR Database) }\end{array}$ & $\begin{array}{l}\text { Primer } \\
\text { type }\end{array}$ & $\begin{array}{l}\text { Primer sequence } \\
\qquad\left(5 \rightarrow 3^{\prime}\right)\end{array}$ & $\begin{array}{l}\text { PCR fragment size } \\
\text { (bp) }\end{array}$ \\
\hline $\begin{array}{l}\text { Arabidopsis thaliana } \\
\text { aldehyde oxidase }\end{array}$ & $\begin{array}{l}\text { Encodes for the enzyme } \\
\text { aldehyde oxidase, catalyzing } \\
\text { a terminal and rate-limiting } \\
\text { step of IAA biosynthesis. }\end{array}$ & AT5G20960 & $\begin{array}{l}\text { For } \\
\text { Rev }\end{array}$ & $\begin{array}{l}\text { ATGGGTGAGAAAGCGATTGACGAAG } \\
\text { CTAATAACCCTTGAAGCTCTGAGACAC }\end{array}$ & 799 \\
\hline $\begin{array}{l}\text { Arabidopsis thaliana } \\
\text { nitrilase }\end{array}$ & $\begin{array}{l}\text { Encodes for the enzyme nitrilase, } \\
\text { catalyzing a terminal, and rate-limiting } \\
\text { step of IAA biosynthesis. }\end{array}$ & AT3G44310 & $\begin{array}{l}\text { For } \\
\text { Rev }\end{array}$ & $\begin{array}{l}\text { GCCCTGAAGTAGCAAGATTGGCTGA } \\
\text { CAATATCAGCTGTGACGAGACCCTC }\end{array}$ & $669 * / 576 * *$ \\
\hline $\begin{array}{l}\text { Arabidopsis thaliana } \\
\text { isopentenyl transferase }\end{array}$ & $\begin{array}{l}\text { Encodes for the enzyme adenylate } \\
\text { isopentenyltransferase, catalyzing } \\
\text { the isopentenylation of AMP, a } \\
\text { rate-limiting step of CK synthesis. }\end{array}$ & AT3G23630 & $\begin{array}{l}\text { For } \\
\text { Rev }\end{array}$ & $\begin{array}{l}\text { ATGGTTGTGATCATGGGTGCCA } \\
\text { CTCTCACCGCCTTCTCATAAGC }\end{array}$ & 655 \\
\hline
\end{tabular}

*Primers of AtNIT were designed in the exon number 3 (forward primer) and 4 (reverse primer). The amplified sequence include intron number 3: this means that RNA has not been spliced. **The am2plified sequence do not include intron number 3: this means that RNA has been spliced and that the intron is the mature messenger RNA. 
the roots (Table 2). In fact, despite the antagonism of metal uptake in the combined treatment, shoot translocation seems to have remained generally unaffected (Table 2). Interestingly, Cd was the most translocated metal compared to $\mathrm{Cu}$ and $\mathrm{Zn}$, as the shoot/root $\mathrm{Cd}$ ratios in the $\mathrm{Cd} / \mathrm{Cu}$ and $\mathrm{Cd} / \mathrm{Zn}$ treatments were 0.62 and 0.73 .

\section{Shoot and root morphology}

The Arabidopsis seedlings observed after 12 days from metal application showed macroscopic differences in shoot and root development and also in shoot color if compared to controls (Figure 1A,B; Table 3). In particular, the mean values $(n=20) \pm S D$ of shoot height (flowering stem), primary root length (Figure 1B), and rosette diameter, three parameters that gives a reasonable idea of plant growth, ${ }^{4,17}$ significantly decreased in the double metal treatments, particularly in the presence of $\mathrm{Cd}$ (Table 3). Shoot colour turned from light green of controls to pale-green of $\mathrm{Cu} / \mathrm{Zn}$ treatment, to yellowish-green of $\mathrm{Cd}$-treated seedlings (Figure 1A).

Microscopic analysis revealed that root general morphology of Arabidopsis was affected by exposure to metals (Figure 1C,D; Table 3). Metal-treated seedlings, in particular those subjected to $\mathrm{Cu} / \mathrm{Zn}$ treatment, were characterized by significant increases in root hairs density and root branching, compared to the other metal treatments (Figure 1C; Table 3). Metals caused also significant increase in mean root diameter compared to controls (Figure 1D; Table 3).

\section{Phytohormone levels}

The levels of IAA in Arabidopsis roots increased significantly when seedling were subjected to metals, up to fivefold in the $\mathrm{Cd} / \mathrm{Cu}$ treatment (770 $\mathrm{nmol} / \mathrm{g} \mathrm{FW})$ and fourfold in the $\mathrm{Cd} / \mathrm{Zn}$ treatment $(618 \mathrm{nmol} / \mathrm{g} \mathrm{FW})$, compared to controls (157 nmol/g FW) (Table 4). In the shoots, IAA levels were particularly low if compared to those detected in the roots and was not detected an IAA increase due to metal exposure (Table 4).

The levels of $t$-ZR and DHZR significantly increased in the presence of metal exposures, both in roots and shoots (Table 4). In general, CK content in the shoots were high if compared to the roots, and showed to be particularly elevated in the $\mathrm{Cd} / \mathrm{Cu}$ and $\mathrm{Cd} / \mathrm{Zn}$ treatments (Table 4). Besides, Zn exposures significantly increased the GA3 levels in the root (1.6-fold in the $\mathrm{Cu} / \mathrm{Zn}$ and $\mathrm{Cd} / \mathrm{Zn}$ treatments, respectively, compared to controls); however, this was not the case of the $\mathrm{Cd} / \mathrm{Cu}$ mixture (Table 4 ). The levels of GA3 in the shoots showed the same significant differences among the treatments observed in roots (Table 4). Finally, although ABA levels in metal-exposed roots showed an upward trend, significant increases due to metal combined exposure were never observed due to the high variability of the measurements (SD) (Table 4). In the shoots, the ABA levels were extremely low, except for the $\mathrm{Cu} / \mathrm{Zn}$-exposed plants, but the values did not significantly differ from the controls.

\section{Reverse transcriptase-polymerase chain reaction analysis}

The RT-PCR analysis of the genes involved in IAA and CK biosynthesis (Table 1) revealed that the $A A O$ (aldehyde oxidase), NIT and AtIPT genes were able to express themselves (a)
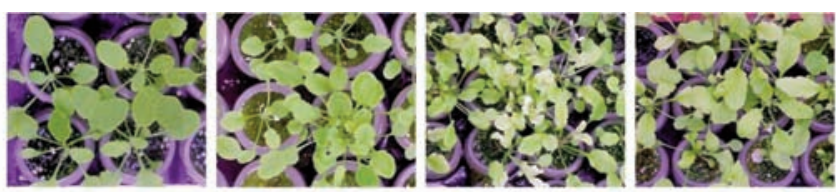

C

CuZn
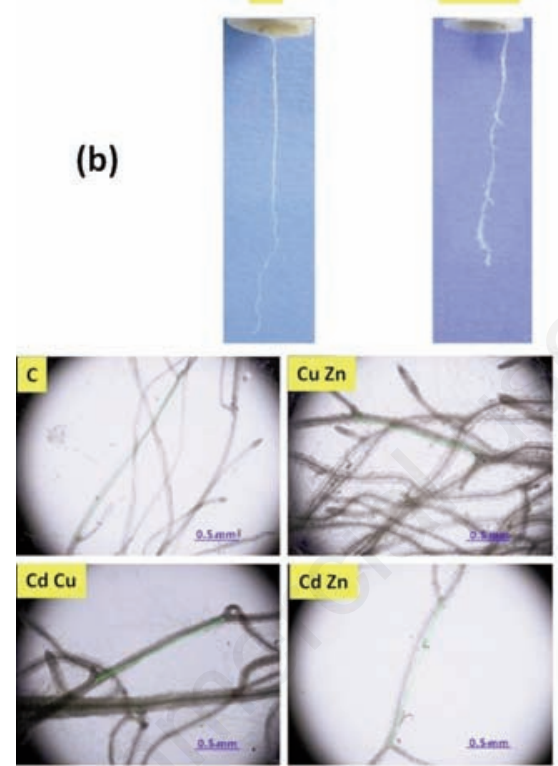

(c)
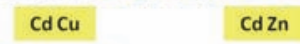

(b)

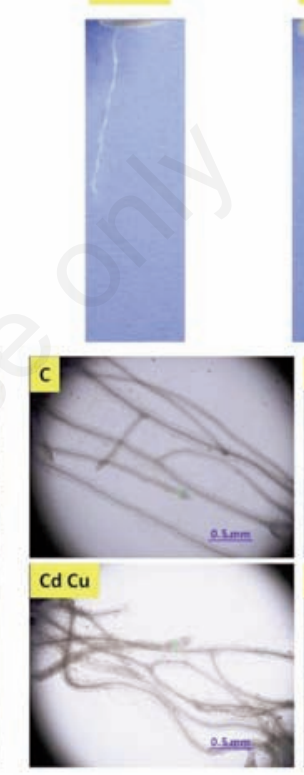

(d)

Figure 1. Macroscopic aspect of seedlings (a) and roots (b) of Arabidopsis seedlings not exposed to metals (C; Control) or exposed for 12 days to $5 \mu \mathrm{M} \mathrm{CuSO}_{4}$ and $150 \mu \mathrm{M}$ $\mathrm{ZnSO}_{4}(\mathrm{Cu} / \mathrm{Zn}), 10 \mu \mathrm{M} \mathrm{CdSO}_{4}$ and $5 \mu \mathrm{M} \mathrm{CuSO}_{4}(\mathrm{Cd} / \mathrm{Cu})$, and $10 \mu \mathrm{M} \mathrm{CdSO}{ }_{4}$ and 150 $\mu \mathrm{MnSO}_{4}(\mathrm{Cd} / \mathrm{Zn})$. Root morphology (c: branching; d: mean diameter) of the same seedlings. Measured branching and diameters are highlighted with yellow segments. Scale bars $=0.5 \mathrm{~mm}$.

Table 2. Concentrations of $\mathrm{Cu}, \mathrm{Zn}$ and $\mathrm{Cd}$ in roots and shoots of Arabidopsis seedlings not exposed to metals (Control), or exposed for 12 days to $5 \mu \mathrm{M} \mathrm{CuSO}_{4}$ and $150 \mu \mathrm{M}$ $\mathrm{ZnSO}_{4}(\mathrm{Cu} / \mathrm{Zn})$, to $10 \mu \mathrm{M} \mathrm{CdSO}{ }_{4}$ and $5 \mu \mathrm{M} \mathrm{CuSO}{ }_{4}(\mathrm{Cd} / \mathrm{Cu})$, and to $10 \mu \mathrm{M} \mathrm{CdSO}{ }_{4}$ and $150 \mu \mathrm{M} \mathrm{ZnSO}_{4}(\mathrm{Cd} / \mathrm{Zn})$.

Cu ( $\mu \mathrm{g} / \mathrm{g} \mathrm{DW}) \quad \operatorname{Zn}(\mu \mathrm{g} / \mathrm{g} \mathrm{DW}) \quad \mathrm{Cd}(\mu \mathrm{g} / \mathrm{g} \mathrm{DW})$

\begin{tabular}{|c|c|c|c|}
\hline \multicolumn{4}{|l|}{ Roots } \\
\hline Control & $5.17 \pm 1.44^{b}$ & $20.68 \pm 4.38^{c}$ & $0.16 \pm 0.04^{c}$ \\
\hline $\mathrm{Cu} / \mathrm{Zn}$ & $816.05 \pm 28.42^{\mathrm{a}}$ & $724.62 \pm 34.75^{\mathrm{a}}$ & $0.35 \pm 0.11^{\mathrm{c}}$ \\
\hline $\mathrm{Cd} / \mathrm{Cu}$ & $839.59 \pm 52.43^{\mathrm{a}}$ & $10.03 \pm 5.64^{\mathrm{c}}$ & $305.39 \pm 81.51^{\mathrm{a}}$ \\
\hline $\mathrm{Cd} / \mathrm{Zn}$ & $3.61 \pm 1.37^{\mathrm{b}}$ & $460.96 \pm 29.30^{\mathrm{b}}$ & $222.36 \pm 34.90^{\mathrm{b}}$ \\
\hline \multicolumn{4}{|l|}{ Shoots } \\
\hline Control & $5.86 \pm 1.58^{b}$ & $19.57 \pm 5.02^{\mathrm{c}}$ & $0.16 \pm 0.04^{b}$ \\
\hline $\mathrm{Cu} / \mathrm{Zn}$ & $230.82 \pm 33.04^{\mathrm{a}}$ & $114.41 \pm 17.34^{\mathrm{a}}$ & $0.14 \pm 0.04^{b}$ \\
\hline $\mathrm{Cd} / \mathrm{Cu}$ & $236.62 \pm 25.07^{\mathrm{a}}$ & $12.06 \pm 4.03^{c}$ & $189.59 \pm 22.59^{\mathrm{a}}$ \\
\hline $\mathrm{Cd} / \mathrm{Zn}$ & $3.54 \pm 0.61^{b}$ & $89.87 \pm 8.72^{\mathrm{b}}$ & $161.48 \pm 25.75^{\mathrm{a}}$ \\
\hline
\end{tabular}

Mean values $(n=10) \pm$ S.D. with different letters for each metal are significantly different between treatments at $P \leq 0.05$, according to Fisher's LSD test. The statistical analysis was performed separately for roots and shoots. 
in roots, independently of metals presence (Figure 2). In fact, all the root samples analyzed (both controls and metal-treated) always reveled the fragments of interest (Figure 2).

\section{Discussion}

The exposition of Arabidopsis seedlings to the metals has determined an effective metal uptake by roots and an efficiently translocation to the shoots (Table 2). Taking into account the differences in metal exposure time and metal concentration used in other experiments, the observed levels of $\mathrm{Cd}$ and $\mathrm{Zn}$ are comparable to those found by other authors. ${ }^{17-19}$ In the two $\mathrm{Cu}$ treatments, Arabidopsis seedlings showed a high capacity to enhance $\mathrm{Cu}$ uptake and translocation to shoots, in contrast to species with high affinity for $\mathrm{Cu}$-rich soil, that usually adopt a Cu-exclusion strategy, even at $\mathrm{Cu}$ concentrations higher than those used in this work. ${ }^{20}$ Interestingly, the relatively long period of contact to metal used in this study (12 d), compared to other studies where the authors used shorter metal treatments, ${ }^{18-21}$ allowed an efficient Cd translocation in Arabidopsis shoots (Table 2). However, the results confirm that, both in the presence of $\mathrm{Cu}$ or $\mathrm{Zn}, \mathrm{Cd}$ was efficiently absorbed by roots and translocated to the shoots (Table 2). The reduction of $\mathrm{Cd}$ content found in the $\mathrm{Cd} / \mathrm{Zn}$ treatment (Table 2) could be due to an interference of root-shoot transport derived from a phytotoxic effect of $\mathrm{Zn}$ in roots, as Smeets et $a l .^{21}$ observed in Arabidopsis for $\mathrm{Cu}$.

Cadmium-modulated plastic development of the root system architecture appears to be a common phenomenon in plants, as Cd toxicity inhibits primary root growth, whereas it promotes lateral root formation. ${ }^{3}$ Increase in lat- eral root primordia under Cd stress has been reported in willow, poplar and maize roots..$^{22,23}$ Our data showed that all the metal combinations caused significant increases in root hairs number and in root branching, particularly evident for the combination $\mathrm{Cu} / \mathrm{Zn}$ (Table 3 ). The key components of the cell cycle and signaltransduction pathways that promote and attenuate auxin-dependent lateral roots initiation and elongation have been identified in

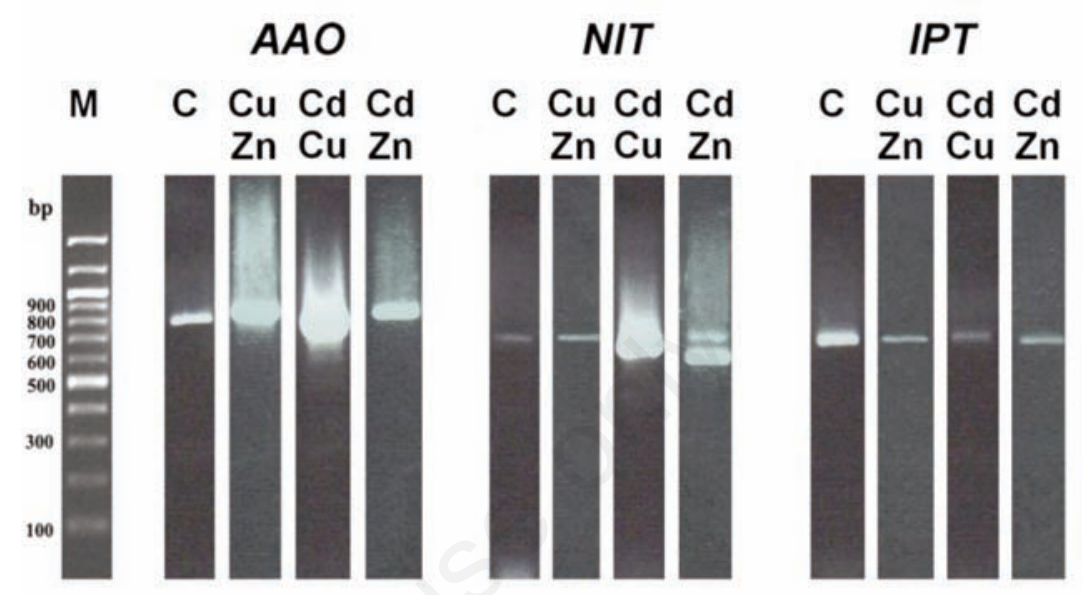

Figure 2. RT-PCR analysis of the genes involved in IAA and CKs biosynthesis in roots of Arabidopsis seedlings not exposed to metals (Control) or exposed for 12 days to $5 \mu \mathrm{M}$ $\mathrm{CuSO}_{4}$ and $150 \mu \mathrm{M} \mathrm{ZnSO}_{4}(\mathrm{Cu} / \mathrm{Zn}), 10 \mu \mathrm{M} \mathrm{CdSO}_{4}$ and $5 \mu \mathrm{M} \mathrm{CuSO}_{4}(\mathrm{Cd} / \mathrm{Cu})$, and 10 $\mu \mathrm{M} \mathrm{CdSO}_{4}$ and $150 \mu \mathrm{M} \mathrm{ZnSO} \mathrm{Z}_{4}(\mathrm{Cd} / \mathrm{Zn}) . \mathrm{M}=100 \mathrm{bp}$ DNA Ladder. The bands on the gel are RNA.

Table 3. Morphometric parameters of Arabidopsis seedlings not exposed to metals (Control) or exposed for 12 days to $5 \mu \mathrm{M} \mathrm{CuSO}_{4}$ and $150 \mu \mathrm{M} \mathrm{ZnSO}_{4}(\mathrm{Cu} / \mathrm{Zn}), 10 \mu \mathrm{M} \mathrm{CdSO}_{4}$ and $5 \mu \mathrm{M} \mathrm{CuSO}_{4}(\mathrm{Cd} / \mathrm{Cu})$, and $10 \mu \mathrm{M} \mathrm{CdSO} \mathrm{O}_{4}$ and $150 \mu \mathrm{M} \mathrm{ZnSO} 4(\mathrm{Cd} / \mathrm{Zn})$.

\begin{tabular}{|c|c|c|c|c|c|c|}
\hline & $\begin{array}{l}\text { Shoot height } \\
(\mathrm{cm})\end{array}$ & $\begin{array}{l}\text { Rosette diameter } \\
\text { (cm) }\end{array}$ & $\begin{array}{l}\text { Primary root length } \\
(\mathrm{cm})\end{array}$ & $\begin{array}{l}\text { Root hairs density } \\
\text { (number mm-1 root) }\end{array}$ & $\begin{array}{c}\text { Root branching } \\
\text { (number mm-1 root) }\end{array}$ & $\begin{array}{l}\text { Mean root diameter } \\
(\mathrm{mm})\end{array}$ \\
\hline Control & $6.4 \pm 0.8^{\mathrm{a}}$ & $3.5 \pm 0.3^{\mathrm{a}}$ & $7.4 \pm 0.7^{\mathrm{a}}$ & $5 \pm 3 c$ & $0.4 \pm 0.4 \mathrm{c}$ & $0.07 \pm 0.01^{\mathrm{c}}$ \\
\hline $\mathrm{Cu} / \mathrm{Zn}$ & $5.2 \pm 0.2^{b}$ & $2.8 \pm 0.5^{b}$ & $6.0 \pm 0.4^{\mathrm{b}}$ & $24 \pm 5^{\mathrm{a}}$ & $1.3 \pm 0.6^{\mathrm{a}}$ & $0.11 \pm 0.05^{b}$ \\
\hline $\mathrm{Cd} / \mathrm{Cu}$ & $4.3 \pm 0.9^{c}$ & $2.1 \pm 0.3 \mathrm{c}$ & $5.2 \pm 0.4^{c}$ & $17 \pm 6^{b}$ & $0.8 \pm 0.2^{\mathrm{b}}$ & $0.15 \pm 0.04^{\mathrm{a}}$ \\
\hline $\mathrm{Cd} / \mathrm{Zn}$ & $4.6 \pm 0.2^{\mathrm{c}}$ & $2.2 \pm 0.3 \mathrm{c}$ & $5.6 \pm 0.8^{c}$ & $17 \pm 4^{b}$ & $0.9 \pm 0.2^{b}$ & $0.17 \pm 0.05^{\mathrm{a}}$ \\
\hline
\end{tabular}

Mean values $(n=20) \pm$ S.D. with different letters are significantly different between treatments at $\mathrm{P} \leq 0.05$, according to Fisher's LSD test. The statistical analysis was performed separately for roots and shoots.

Table 4. Levels of indole-3-acetic acid (IAA), trans-zeatin riboside (t-ZR), dihydrozeatin riboside (DHZR), gibberellic acid (GA3) and abscisic acid (ABA) in roots and shoots of Arabidopsis seedlings not exposed to metals (Control) or exposed for 12 days to $5 \mu \mathrm{MM} \mathrm{CuSO}_{4}$ and $150 \mu \mathrm{M} \mathrm{ZnSO}_{4}(\mathrm{Cu} / \mathrm{Zn}), 10 \mu \mathrm{M} \mathrm{CdSO}_{4}$ and $5 \mu \mathrm{M} \mathrm{CuSO}_{4}(\mathrm{Cd} / \mathrm{Cu})$, and $10 \mu \mathrm{M} \mathrm{CdSO}{ }_{4}$ and $150 \mu \mathrm{M} \mathrm{ZnSO}{ }_{4}(\mathrm{Cd} / \mathrm{Zn})$.

\begin{tabular}{|c|c|c|c|c|c|}
\hline & $\begin{array}{c}\text { IAA } \\
(\mathrm{nmol} \mathrm{g}-1 \mathrm{FW})\end{array}$ & $\begin{array}{c}\mathrm{t}-\mathrm{ZR} \\
(\mathrm{nmol} \mathrm{g}-1 \mathrm{FW})\end{array}$ & $\begin{array}{c}\text { DHZR } \\
\text { (nmol g-1 FW) }\end{array}$ & $\begin{array}{c}\text { GA3 } \\
(\mathrm{nmol} \mathrm{g-1} \mathrm{FW)}\end{array}$ & $\begin{array}{c}\text { ABA } \\
(\mathrm{nmol} \mathrm{g}-1 \mathrm{FW})\end{array}$ \\
\hline $\begin{array}{l}\text { Roots } \\
\text { Control } \\
\mathrm{Cu} / \mathrm{Zn} \\
\mathrm{Cd} / \mathrm{Cu} \\
\mathrm{Cd} / \mathrm{Zn}\end{array}$ & $\begin{array}{l}157.29 \pm 11.80^{\mathrm{d}} \\
574.14 \pm 68.90^{\mathrm{b}} \\
770.27 \pm 48.53^{\mathrm{a}} \\
618.28 \pm 86.56^{\mathrm{a}}\end{array}$ & $\begin{array}{l}7.80 \pm 0.44^{\mathrm{b}} \\
18.07 \pm 0.72^{\mathrm{a}} \\
12.02 \pm 2.10^{\mathrm{a}} \\
11.94 \pm 0.96^{\mathrm{a}}\end{array}$ & $\begin{array}{c}8.20 \pm 1.66^{\mathrm{b}} \\
15.69 \pm 2.35^{\mathrm{a}} \\
12.32 \pm 1.58^{\mathrm{a}} \\
11.50 \pm 0.58^{\mathrm{a}}\end{array}$ & $\begin{array}{l}5.53 \pm 0.35^{\mathrm{b}} \\
8.97 \pm 0.36^{\mathrm{a}} \\
2.70 \pm 0.72^{\mathrm{b}} \\
8.60 \pm 1.51^{\mathrm{a}}\end{array}$ & $\begin{array}{l}3.02 \pm 1.37^{\mathrm{a}} \\
8.62 \pm 3.95^{\mathrm{a}} \\
6.13 \pm 3.31^{\mathrm{a}} \\
5.90 \pm 2.84^{\mathrm{a}}\end{array}$ \\
\hline $\begin{array}{l}\text { Shoots } \\
\text { Control } \\
\mathrm{Cu} / \mathrm{Zn} \\
\mathrm{Cd} / \mathrm{Cu} \\
\mathrm{Cd} / \mathrm{Zn}\end{array}$ & $\begin{array}{l}57.00 \pm 2.28^{\mathrm{a}} \\
56.93 \pm 5.12^{\mathrm{a}} \\
68.91 \pm 2.76^{\mathrm{a}} \\
59.06 \pm 7.68^{\mathrm{a}}\end{array}$ & $\begin{array}{c}24.62 \pm 1.97^{\mathrm{c}} \\
132.76 \pm 9.96^{\mathrm{b}} \\
237.84 \pm 30.92^{\mathrm{a}} \\
212.63 \pm 17.01^{\mathrm{a}}\end{array}$ & $\begin{array}{c}26.13 \pm 4.65 c \\
163.79 \pm 10.19^{b} \\
229.73 \pm 18.38^{a} \\
190.43 \pm 15.23^{a}\end{array}$ & $\begin{array}{l}1.60 \pm 0.16^{\mathrm{b}} \\
7.48 \pm 0.56^{\mathrm{a}} \\
2.35 \pm 0.28^{\mathrm{b}} \\
6.57 \pm 0.37^{\mathrm{a}}\end{array}$ & $\begin{array}{l}0.80 \pm 0.15^{\mathrm{a}} \\
2.17 \pm 0.38^{\mathrm{a}} \\
0.29 \pm 0.06^{\mathrm{a}} \\
0.22 \pm 0.04^{\mathrm{a}}\end{array}$ \\
\hline
\end{tabular}

Mean values $(\mathrm{n}=10) \pm$ S.D. with different letters are significantly different ${ }^{\mathrm{b}}$ etween treatments at $\mathrm{P} \leq 0.05$, according to Fisher's LSD test. The statistical analysis was performed separately for roots and shoots. 
Arabidopsis, ${ }^{24}$ and a recent study of Sofo et al. ${ }^{17}$ reviewed the strong relationship between metals and IAA balance in this species. Pasternak et al. ${ }^{4}$ observed that Arabidopsis Cu-exposed plants present significantly increased root hair density and an acceleration of the emergence of lateral roots, with phenotypes that resemble those of plants altered in auxin synthesis. In Cd-exposed Arabidopsis seedlings, this metal markedly induced lateral root occurrence and inhibition of auxin transport suppressed lateral root formation, suggesting that $\mathrm{Cd}$ affects lateral root occurrence by modulating the auxin pathway. ${ }^{25}$ As IAA is involved in lateral and adventitious roots initiation and emergence by changes in cell division, expansion and differentiation, ${ }^{15}$ significant increase of this hormone in roots of metal-treated plants (Table 4) could be one of the causes for the higher root branching (Figure 1C; Table 3).

It is known that CKs and IAA have antagonistic roles in root development: IAA promotes the formation of lateral and adventitious roots, whereas CKs reverse such effect. ${ }^{26}$ Studies of hormonal influences on root growth have emphasized the importance of both IAA and CKs in root functionality and morphology in Arabidopsis. ${ }^{15}$ On this basis, we hypothesized that the increase in root branching could be imputed to the alteration that metals trigger to the hormonal balance, in particular to the auxin/CKs ratio. ${ }^{4} \mathrm{An}$ increase in IAA/CKs ratio promotes the formation of lateral roots and, of consequence, increased root branching. ${ }^{25,26}$ This behavior effectively occurred in our Arabidopsis seedlings, were IAA/CKs $>17$ in roots of the double metal treatment (vs. about 10 of control roots) were accompanied to higher root branching (Table 4).

Unfortunately, the complete picture of IAA biosynthesis is still not well defined. ${ }^{16,27}$ Furthermore, $A A O$ and $N I T$ genes, despite their key role of $A A O$ and NIT in the IAA synthetic pattern, ${ }^{16}$ were scarcely studied if compared, for instance, to YUCCAs genes. ${ }^{27}$ In roots, the expression of the gene $A A O$, encoding for the enzyme aldehyde oxidase, catalyzing the final oxidation of indole-3-acetaldehyde to IAA, and that of NIT gene, encoding for the enzyme nitrilase, catalyzing the final reaction of IAA biosynthetic pattern, ${ }^{12,26}$ were always able to express themselves (Figure 2). The RT-PCR analysis on the expression of the gene IPT, encoding the isopentenyl transferase, that catalyzes the isopentenylation of AMP in the biosynthetic pattern of CKs, ${ }^{15,28}$ showed that their expression in metal-treated seedlings was not caused by metal exposure, as gene transcription was active both with or without metals (Figure 2). This suggests that the observed changes in IAA levels in the roots of metal-exposed plants (Table 4), were likely due to a fine level regulation and not simply to the mere activation/induction of gene expression, or to post-transcriptional regulation mechanisms.

The presence of $\mathrm{Cd}$ inhibits root elongation and influences root anatomy, but apoplastic movement of toxic $\mathrm{Cd}$ to the xylem can be restricted by the development of the exodermis, endodermis, and other extracellular barriers. $^{23}$ The observed increase in root CKs, significant in all the metal double treatments (Table 4), could be one of the causes for the increase in root diameter of seedlings exposed to metals, as CKs are strongly related to rhizodermal and parenchymal cell proliferation and root thickening by lignin production and deposition. ${ }^{12}$ As suggested by Dŭrčeková et al. ${ }^{29}$ it is also probable that $\mathrm{Cd}$ inhibited the primary root growth (Table 3 ) as a consequence of Cdstimulated premature root differentiation and development, involving xylogenesis, induction of lateral roots, and growth of lateral roots and root hairs, as found by other authors..$^{29,30}$ Thus, in several plant species, the above events can be interpreted as responses caused by a $\mathrm{Cd}$ induced precocious ageing compared with unexposed ones. In our case, we suggest that the observed increase in root diameter (Figure 1D; Table 3) as a probable consequence of metal-induced xylogenesis, could act as a barrier to protect root from the toxic metals, and particularly from $\mathrm{Cd}$, while the increasing of root branching could be considered as an avoidance strategy of the roots in order to redirect the root development away from zones containing metals, according to the lateral root initiation hypothesis postulated by Aloni et al. ${ }^{26}$

The morphological changes induced by the metals also reflect the different levels of GA3, an hormone involved in the promotion of elongation in axial organs, such as main root. ${ }^{15}$ The root level of GA3 after the double exposure containing $\mathrm{Zn}$ were higher to the value of control seedlings (Table 4), suggesting a specific role of this metal in GA3 production and/or accumulation. Generally, ABA acts as a general inhibitor of root and shoot growth and metabolism, and negatively affects the synthesis of proteins and nucleic acids, even though these effects vary with tissue and developmental stage. ${ }^{12}$ This hormone generally accumulates in response to numerous stresses, such as drought, high salt and cold, where an overlap in the expression pattern of stress genes occurs, ${ }^{11,12}$ but not in response to metal treatments. ${ }^{15}$ Our data showed no significant differences in ABA levels between control and metaltreated seedlings in both roots and shoots (Table 4), indicating that this hormone is not involved in the growth inhibition due to metal exposure, at the concentrations of $\mathrm{Cd}, \mathrm{Cu}$ and $\mathrm{Zn}$ here used.

\section{Conclusions}

Our study demonstrated that the molecular, biochemical, physiological and morphological characteristics of Arabidopsis thaliana are strongly affected by double combined exposures to $\mathrm{Cd}, \mathrm{Cu}$ and $\mathrm{Zn}$. Root traits of Arabidopsis were closely related to the applied metal stress. Indeed, the root morphological alterations that resulted in an increased surface area, such as the formation of root hairs and lateral roots, could be defined as signs of response to metal stress in terms of specific, functionally-addressed, reorientation of growth. The elevated root system plasticity observed in this species could be of importance to better understand the mechanisms driving the response of plants to the variation of mineral availability in the soil, and the manner in which the architecture of the root system is shaped by environmental and hormonal stimuli.

\section{References}

1. Vangronsveld J, Herzig R, Weyens N, et al. Phytoremediation of contaminated soils and groundwater: lessons from the field. Environ Sci Pollut Res 2009;16:765-94.

2. Kabata-Pendias A, Mukherjee, AB. Trace elements from soil to human. Berlin: Springer-Verlag; 2007.

3. Cuypers A, Plusquin M, Remans T, et al. Cadmium stress: an oxidative challenge. Biometals 2003;23:927-40.

4. Pasternak T, Rudas V, Potters G, Jansen MAK. Morphogenic effects of abiotic stress: reorientation of growth in Arabidopsis thaliana seedlings. Environ Exp Bot 2005;53:299-314.

5. Kai K, Horita J, Wakasa K, Miyagawa $\mathrm{H}$. Three oxidative metabolites of indole-3acetic acid from Arabidopsis thaliana. Phytochemistry 2007;68:1651-63.

6. Hansen BG, Halkier BA. New insight into the biosynthesis and regulation of indole compounds in Arabidopsis thaliana. Planta 2005;221:603-6.

7. Ludwig-Müller J. Indole-3-butyric acid synthesis in ecotypes and mutants of Arabidopsis thaliana under different growth conditions. J Plant Physiol 2007; 164:47-59.

8. Sharma SS, Kumar V. Responses of wild type and abscisic acid mutants of Arabidopsis thaliana to cadmium. J Plant Physiol 2002;159:1323-27.

9. Phillips LW. Gibberellins in Arabidopsis. Plant Physiol Biochem 1998;36:115-24.

10. Yamaguchi S. Gibberellin biosynthesis in Arabidopsis. Phytochem Rev 2006;5:39-47. 
11. Peleg Z, Blumwald E. Hormone balance and abiotic stress tolerance in crop plants. Curr Opin Plant Biol 2011;14:290-5.

12. Srivastava LM. Plant, growth and development. Hormones and environment. San Diego: Academic Press; 2002.

13. Vitti A, Nuzzaci M, Scopa, A, et al. Auxin and cytokinin metabolism and root morphological modifications in Arabidopsis thaliana seedlings infected with Cucumber Mosaic Virus (CMV) or exposed to cadmium. Int J Mol Sci 2013;14:6889902.

14. Lasat MM, Baker AJM, Kochian LV. Physiological characterization of root $\mathrm{Zn} 2+$ absorption and translocation to shoots in Zn hyperaccumulator and nonaccumulator species of Thlaspi. Plant Physiol 1996;112:1715-22.

15. Hedden P, Thomas SG. Plant hormone signalling. Oxford: Blackwell Publishing; 2006.

16. Yamamoto Y, Kamiya N, Morinaka Y, et al. Auxin biosynthesis by the YUCCA genes in rice. Plant Physiol 2007;143:1362-71.

17. Sofo A, Scopa A, Remans T, et al. Biochemical and physiological responses of Arabidopsis thaliana exposed to cadmium, copper and zinc. In: Anjum N, Ahmad I, Pereira ME, eds. The plant family Brassicaceae: contribution towards phy- toremediation. New York: Springer; 2012. pp. 239-263.

18. Herbette S, Taconnat L, Hugouvieux V, et al. Genome-wide transcriptome profiling of the early cadmium response of Arabidopsis roots and shoots. Biochimie 2006;88:1751-65.

19. Tennstedt P, Peisker D, Böttcher C, et al. Phytochelatin synthesis is essential for the detoxification of excess zinc and contributes significantly to the accumulation of zinc. Plant Physiol 2009;149:938-48.

20. Faucon MP, Chipeng F, Verbruggen N, et al. Copper tolerance and accumulation in two cuprophytes of South Central Africa: Crepidorhopalon perennis and C. tenuis (Linderniaceae). Environ Exp Bot 2012;84:11-6.

21. Smeets K, Opdenakker K, Remans T, et al. Oxidative stress-related responses at transcriptional and enzymatic levels after exposure to $\mathrm{Cd}$ or $\mathrm{Cu}$ in a multipollution context. J Plant Physiol 2009;166:1982-92.

22. Lunáčková L, Šottníková A, Masarovičová E, et al. Comparison of cadmium effect on woody plants in response to different cultivation conditions. Biol Plant 2003;47:40311.

23. Lux A, Martinka M, Vaculík M, White PJ. Root responses to cadmium in the rhizosphere: a review. J Exp Bot 2011;62:21-37.
24. Casimiro I, Beeckman T, Graham N, et al. Dissecting Arabidopsis lateral root development. Trends Plant Sci 2003;8:165-71.

25. Xu J, Wang W, Sun J, et al. Involvement of auxin and nitric oxide in plant Cd-stress responses. Plant Soil 2011;346:107-19.

26. Aloni R, Aloni E, Langhans M, Ullrich CI. Role of cytokinin and auxin in shaping root architecture: regulating vascular differentiation, lateral root initiation, root apical dominance and root gravitropism. Ann Bot 2006;97:883-93.

27. Kim JI, Baek D, Park HC, et al. Overexpression of Arabidopsis YUCCA6 in potato results in high-auxin developmental phenotypes and enhanced resistance to water deficit. Mol Plant 2013;6:337-49.

28. Miyawaki K, Tarkowski P, MatsumotoKitano M, et al. Roles of Arabidopsis ATP/ADP isopentenyltransferases and tRNA isopentenyltransferases in $\mathrm{CK}$ biosynthesis. Proc Natl Acad Sci USA 2006;103:16598-603.

29. Dŭrčeková K, Huttová J, Mistrík I, et al. Cadmium induces premature xylogenesis in barley roots. Plant Soil 2007;290:61-8.

30. Vitória AP, Rodriguez APM, Cunha M, et al. Structural changes in radish seedlings exposed to cadmium. Plant Growth Regul 2003;47:561-68. 